\title{
Economic Growth and Government Debt of Six Large National Economies before and after the 2008 Financial Crisis
}

\author{
Jean $\mathrm{Loo}^{1} \&$ Haihong $\mathrm{He}^{2}$ \\ ${ }^{1}$ Professor, Department of Finance, California State University Los Angeles, USA \\ ${ }^{2}$ Professor, Department of Accounting. California State University Los Angeles, USA \\ Correspondence: Jean Loo, Professor, Department of Finance, California State University Los Angeles, USA
}

Received: July 2, 2018

Accepted: August 23, 2018

Online Published: August 28, 2018

doi:10.5430/afr.v7n4p30

URL: https://doi.org/10.5430/afr.v7n4p30

\begin{abstract}
This paper investigates the causal relationship between economic growth and government debt of six large national economies ten years before and ten years after the 2008 financial crisis. There have been numerous studies on whether government debt has any negative effect on economic growth. The results of most empirical studies are mixed depending on the levels of government debt, the countries included in the sample, the sample periods chosen, and the methodologies employed. This paper focuses on six large national economies, namely, the United States, Japan, Germany, the United Kingdom, France, and Canada during the periods ten years before and ten years after the most recent financial crisis of 2008. It is found that there are significant increases in the level of government debt and decreases in economic growth during the ten years after the financial crisis for all six countries. Our results show that the hypothesis that government debt does not Granger-cause economic growth is rejected for all six countries combined for the pre- financial crisis sub-period and the whole sample period, but not for the post financial crisis sub-period. The hypothesis that economic growth does not Granger-cause government debt is also rejected for both the pre- and post- financial crisis sub-periods as well as for the whole period. In short, our investigation documented a bi-directional Granger causality between government debt and economic growth during the periods ten years before the 2008 financial crisis, ten years after, and the two periods combined. The evidence suggests that economic growth contributed to reduced government debt and that excess government debt hindered economic growth.
\end{abstract}

Keywords: economic growth, government debt, Granger causality

\section{Introduction}

The level of government debt of most countries has increased significantly after the recent financial crisis of 2008. There are concerns whether such increases in government debt may hinder economic growth. According to Keynesian effects, government debt and public expenses contribute to economic growth especially in the short-run and at moderate levels of government debt. However, the non-Keynesian effects argue that government debt and public expenses crowding out private consumption and investment cause economic growth to slow in the long-run and at high level of government debt (Modigliani 1961). Others such as Barro (1989) argue that increases in government debt initially cause economy to grow and subsequently to slow, thus having little effect on economic growth.

There have been numerous empirical investigations on the effect of government debt on economic growth. The results are mixed depending on the countries included in the sample, the levels of government debt, the sample periods chosen, and the methodologies used. For example, Reinhart and Rogoff (2010) conducted their investigation covering forty-four countries during an extensive sample period of two hundred years. They found a weak relationship between government debt and economic growth below a threshold of $90 \%$ government debt to Gross Domestic Product (GDP) ratio. Over that threshold economic growth begins to slow as government debt increases. Afonso and Jales (2013) documented a negative effect of government debt on economic growth using a sample of 155 countries over the period of 1970 to 2008 for both high and low levels of government debt. Baum, Checherita-Westphal, \& Rother (2013) reported that the effect of government debt on economic growth is positive in the short-run and becomes insignificant at a moderate level of government debt, while the effect is negative at a high level of government debt. Panizza and Presbitero (2012) found uncertain results between government debt and economic growth depending on the models used. Herndon, Ash, and Pollin (2013) also documented an ambiguous 
relationship between government debt and economic growth. Some researchers such as Easterly (2001) studied whether slow economic growth causes government debt to rise in certain countries. Abbas and Christensen (2007) found bi-directional causality between government debt and economic growth. They documented that public debt has a significant positive impact on per capital income, and economic growth has a significant positive impact on public debt.

The objective of this paper is to conduct an investigation of a bi-directional Granger causality relationship between government debt and economic growth of six large national economies ten years before (from 1998 to 2007) and ten years after (from 2008 to 2017) the 2008 financial crisis as there have been significant increases in the level of government debt causing concerns of its negative impact on economic growth. Our results show that the hypothesis that government debt does not Granger-cause economic growth is rejected for the 1998 to 2007 sub-period before the financial crisis and for the 1998 to 2017 whole-period for all six countries combined. We also found that the hypothesis that economic growth does not Granger-cause government debt is rejected for all six countries combined for both sub-periods as well as the whole-period. The evidence suggests that government debt hindered economic growth and that economic growth contributed to a reduction in government debt.

\section{Sample Description}

The data used in this paper are obtained from Organization for Economic Co-operation and Development (OECD) and the World Bank data bases. The data include quarterly government debt as a percentage of GDP and the quarterly GDP rate of change from 1998 to 2017 for six large national economies consisting of the United States, Japan, Germany, the United Kingdom, France, and Canada. The rate of change in GDP is used as the proxy for economic growth. The whole sample period ranges from 1998 to 2017. The two sub-periods are 1998 to 2007 (the pre 2008 financial crisis period), and 2008 to 2017 (the post 2008 financial crisis period).

Table 1 provides sample descriptive information of the two variables used, GDP growth rate and government debt as a percentage of GDP during the three alternative sample periods. It shows that the economic growth slowed for all six countries after the 2008 financial crisis. The declines in the average economic growth rate were statistically significant for the United States, the United Kingdom, France, and Canada. The average GDP growth rate per quarter of all six countries went down from $0.57 \%$ before the financial crisis to $0.28 \%$ after the financial crisis, which is also statistically significant. In the meantime, the government debt level increased for all six countries except Canada, and the changes were statistically significant. The average government debt as a percentage of GDP went up from $59.67 \%$ to $86.51 \%$ after the financial crisis; the average increase in government debt was also statistically significant. Among all six countries, Japan had the highest government indebtedness along with the lowest GDP growth rate. On the other hand, Canada had a low level of government debt and a high level of economic growth. 
Table 1. Descriptive Statistics

\begin{tabular}{|c|c|c|c|c|c|c|c|c|c|c|}
\hline & \multicolumn{5}{|c|}{ Economic Growth (\%) } & \multicolumn{5}{|c|}{ Debt/GDP (\%) } \\
\hline & Mean & Std & Min & Med & Max & Mean & Std & Min & Med & Max \\
\hline \multicolumn{11}{|c|}{ 1998-2017 } \\
\hline US & 0.54 & 0.62 & -2.11 & 0.60 & 1.89 & 72.23 & 18.53 & 51.30 & 62.75 & 99.46 \\
\hline Japan & 0.20 & 1.02 & -4.88 & 0.25 & 2.44 & 145.30 & 39.50 & 72.43 & 138.30 & 201.42 \\
\hline Germany & 0.35 & 0.82 & -4.49 & 0.41 & 2.05 & 42.52 & 4.66 & 36.04 & 40.97 & 51.71 \\
\hline UK & 0.48 & 0.59 & -2.18 & 0.55 & 1.75 & 59.27 & 22.72 & 35.90 & 42.39 & 91.06 \\
\hline France & 0.38 & 0.48 & -1.67 & 0.43 & 1.23 & 70.21 & 12.89 & 54.43 & 63.91 & 90.85 \\
\hline Canada & 0.59 & 0.64 & -2.28 & 0.63 & 1.81 & 49.43 & 7.70 & 36.86 & 48.72 & 70.48 \\
\hline ALL & 0.42 & 0.72 & -4.88 & 0.50 & 2.44 & 73.41 & 40.27 & 35.90 & 56.89 & 201.42 \\
\hline \multicolumn{11}{|c|}{ 1998-2007 } \\
\hline US & 0.73 & 0.51 & -0.32 & 0.75 & 1.89 & 56.28 & 3.34 & 51.30 & 55.80 & 65.42 \\
\hline Japan & 0.26 & 0.66 & -1.38 & 0.31 & 1.94 & 111.64 & 21.61 & 72.43 & 113.79 & 137.57 \\
\hline Germany & 0.41 & 0.59 & -1.21 & 0.36 & 1.63 & 38.80 & 1.64 & 36.04 & 38.72 & 41.57 \\
\hline UK & 0.70 & 0.37 & 0.07 & 0.72 & 1.75 & 39.25 & 2.09 & 35.90 & 39.52 & 42.42 \\
\hline France & 0.57 & 0.33 & -0.20 & 0.65 & 1.23 & 58.16 & 2.38 & 54.43 & 59.13 & 61.50 \\
\hline Canada & 0.76 & 0.50 & -0.15 & 0.71 & 1.81 & 52.02 & 9.77 & 36.86 & 51.21 & 70.48 \\
\hline ALL & 0.57 & 0.53 & -1.38 & 0.58 & 1.94 & 59.67 & 27.02 & 35.90 & 54.48 & 137.57 \\
\hline \multicolumn{11}{|c|}{ 2008-2017 } \\
\hline US & 0.36 & 0.66 & -2.11 & 0.50 & 1.28 & 88.18 & 12.77 & 56.50 & 94.93 & 99.46 \\
\hline Japan & 0.14 & 1.29 & -4.88 & 0.22 & 2.44 & 178.96 & 19.23 & 139.04 & 187.84 & 201.42 \\
\hline Germany & 0.30 & 1.00 & -4.49 & 0.43 & 2.05 & 45.95 & 3.83 & 38.99 & 45.37 & 51.71 \\
\hline UK & 0.26 & 0.69 & -2.18 & 0.44 & 1.15 & 79.30 & 14.79 & 41.70 & 87.32 & 91.06 \\
\hline France & 0.19 & 0.52 & -1.67 & 0.22 & 1.05 & 79.85 & 9.15 & 58.55 & 81.84 & 90.85 \\
\hline Canada & 0.42 & 0.72 & -2.28 & 0.53 & 1.39 & 46.84 & 3.29 & 37.19 & 46.94 & 50.78 \\
\hline ALL & 0.28 & 0.85 & -4.88 & 0.42 & 2.44 & 86.51 & 46.11 & 37.19 & 79.96 & 201.42 \\
\hline
\end{tabular}

The mean values for 2008-2017 in bold are statistically different from those for 1998-2007.

\section{Statistical Analysis}

The Granger-causality that government debt does not cause economic growth is tested by using the unrestricted regression model and the restricted model described below following Granger (2004).

Unrestricted model: Growth $_{t}=\alpha_{0}+\alpha_{1}$ Growth $_{t-1}+\alpha_{2}$ Growth $_{t-2}+\alpha_{3}$ Debt $_{t-1}+\alpha_{4}$ Debt $_{t-2}+\varepsilon_{t}$

Restricted model: Growth $_{t}=\alpha_{0}+\alpha_{1}$ Growth $_{t-1}+\alpha_{2}$ Growth $_{t-2}+\varepsilon_{t}$

H0: $\alpha_{3}=\alpha_{4}=0$

The variable Growth is the rate of change in GDP, and the variable Debt is the government debt to GDP ratio. The one-period and two-period lagged values of the variables Growth and Debt are used as the explanatory variables.

The hypothesis that economic growth does not Granger-cause government debt is tested by using the following unrestricted model and restricted model.

Unrestricted model: Debt $_{t}=\alpha_{0}+\alpha_{1}$ Growth $_{t-1}+\alpha_{2}$ Growth $_{t-2}+\alpha_{3}$ Debt $_{t-1}+\alpha_{4}$ Debt $_{t-2}+\varepsilon_{t}$

Restricted model: Debt $_{t}=\alpha_{0}+\alpha_{1}$ Debt $_{t-1}+\alpha_{2}$ Debt $_{t-2}+\varepsilon_{t}$ 
H0: $\alpha_{1}=\alpha_{2}=0$

The Chi-square test statistics for both hypotheses can be derived by the equation (7) below.

$\mathrm{Tx}(\mathrm{RSSe}-\mathrm{RSSu}) / \mathrm{RSSu} \sim \mathrm{Chi}$-square $(\mathrm{p})$

RSSe is the sum of squared residuals of the restricted model; RSSu is the sum of squared residuals of the unrestricted model; $\mathrm{p}$ is the number of time lags used in the model; $\mathrm{T}$ is the number of observations. The hypothesis that government debt does not cause economic growth or economic growth does not cause government debt is rejected if the chi-square test statistics is greater than the specified critical value.

\section{Empirical Results}

Table 2 reports the chi-square test statistics and p-values for each of the six countries and all six countries combined for all three sample periods. For the entire sample period, the hypothesis that government debt does not Granger-cause economic growth is rejected for all six countries combined, and individually for the United States, Germany, France and Canada. For the pre- financial crisis period, the hypothesis that government debt does not Granger-cause economic growth is rejected for six countries combined, and individually for United States, Japan, Germany and France. The hypothesis is not rejected for all six countries combined, but rejected individually for the United States, the United Kingdom, France and Canada during the post 2008 financial crisis period. Based on the results for all countries combined, it is found that debt did have significant effects on economic growth prior to the financial crisis; however, debt had insignificant effect on economic growth post 2008 financial crisis. The un-tabulated regression coefficients further show that government debt had a negative effect on economic growth in most cases. Among the six countries in our sample, the effect of debt on the economic growth appeared to be the same between the two sub-periods only for the United States and France, and it was different between the two sub-periods for the other four countries. Japan and Germany had debt causing economic growth in the pre- financial crisis period but not in the post-financial crisis period while the United Kingdom and Canada had debt causing economic growth in the post-financial crisis period but not in the pre-financial crisis period.

Table 2. Government debt does not granger-cause economic growth

Unrestricted model: Growt $_{t}=\alpha_{0}+\alpha_{1}$ Growth $_{t-1}+\alpha_{2}$ Growth $_{t-2}+\alpha_{3}$ Debt $_{t-1}+\alpha_{4}$ Debt $_{t-2}+\varepsilon_{t}$

Restricted model: Growth $_{t}=\alpha_{0}+\alpha_{1}$ Growth $_{t-1}+\alpha_{2}$ Growth $_{t-2}+\varepsilon_{t}$

H0: $\alpha_{3}=\alpha_{4}=0$

\begin{tabular}{lllllll}
\hline & $1998-2017$ & & $1998-2007$ & & $2008-2017$ \\
& Chi-square & P-value & Chi-square & P-value & Chi-square & P-value \\
\hline US & 5.46 & $0.07^{*}$ & 14.50 & $0.00^{* * *}$ & 25.9 & $0.00^{* * * *}$ \\
Japan & 2.81 & 0.25 & 9.91 & $0.01^{* * *}$ & 3.44 & 0.18 \\
Germany & 7.87 & $0.02^{* *}$ & 16.59 & $0.00^{* * *}$ & 3.47 & 0.18 \\
UK & 0.14 & 0.93 & 0.07 & 0.96 & 17.44 & $0.00^{* * *}$ \\
France & 6.46 & $0.04^{* *}$ & 17.69 & $0.00^{* * *}$ & 6.99 & $0.03^{* *}$ \\
Canada & 12.59 & $0.00^{* * *}$ & 4.33 & 0.11 & 13.29 & $0.00^{* * *}$ \\
ALL & 11.58 & $0.00^{* * *}$ & 21.43 & $0.00^{* * *}$ & 0.25 & 0.88 \\
\hline
\end{tabular}

$* * *, * *, *$ statistically significant at the $1 \%, 5 \%, 10 \%$ levels, respectively

Table 3 provides the chi-square test statistics for the hypothesis that economic growth does not Granger-cause government debt. The hypothesis is rejected for all six countries combined, and individually for every country during the whole sample period. It is rejected for all six countries combined, and individually for the Unites States and Canada during the pre-2008 financial crisis period. The hypothesis is rejected for all six countries combined, and individually for the United States, Japan, the United Kingdom, France and Canada during the post-financial crisis period. It is further documented that economic growth had a negative effect on government indebtedness during all three sample periods based on the un-tabulated regression coefficients. When comparing the results of two sub-periods around the 2008 financial crisis, we found that the effect of economic growth on debt was the same for the United States and Germany, but not the same for the other countries. 
Table 3. Economic growth does not granger-cause government debt

Unrestricted model: Debt $_{t}=\alpha_{0}+\alpha_{1}$ Growth $_{t-1}+\alpha_{2}$ Growth $_{t-2}+\alpha_{3}$ Debt $_{t-1}+\alpha_{4}$ Debt $_{t-2}+\varepsilon_{t}$

Restricted model: Debt $_{t}=\alpha_{0}+\alpha_{1}$ Debt $_{t-1}+\alpha_{2}$ Debt $_{t-2}+\varepsilon_{t}$

H0: $\alpha_{1}=\alpha_{2}=0$

\begin{tabular}{lllllll}
\hline & $1998-2017$ & & $1998-2007$ & & $2008-2017$ & \\
& Chi-square & P-value & Chi-square & P-value & Chi-square & P-value \\
\hline United States & 22.89 & $0.00^{* * *}$ & 6.64 & $0.04^{* *}$ & 9.20 & $0.01^{* * *}$ \\
Japan & 10.29 & $0.01^{* * *}$ & 0.46 & 0.80 & 5.41 & $0.07^{*}$ \\
Germany & 4.79 & $0.09^{*}$ & 2.26 & 0.32 & 3.15 & 0.21 \\
United Kingdom & 21.62 & $0.00^{* * *}$ & 1.39 & 0.50 & 6.83 & $0.03^{* *}$ \\
France & 30.21 & $0.00^{* * *}$ & 4.61 & 0.10 & 11.84 & $0.00^{* * *}$ \\
Canada & 18.83 & $0.00^{* * *}$ & 8.46 & $0.01^{* * *}$ & 5.62 & $0.06^{*}$ \\
ALL & 67.47 & $0.00^{* * *}$ & 25.37 & $0.00^{* * *}$ & 34.42 & $0.00^{* * *}$ \\
\hline
\end{tabular}

$* * *, * *, *$ statistically significant at the $1 \%, 5 \%, 10 \%$ levels, respectively

\section{Conclusion}

This paper examines whether government debt contributes negatively to economic growth for six large national economies of the United States, Japan, Germany, the United Kingdom, France, and Canada ten years before and ten years after the 2008 financial crisis. The hypotheses that government debt does not Granger-cause economic growth and that economic growth does not Granger-cause government debt are tested. The results suggest that the hypothesis that government debt does not Granger-cause economic growth was rejected for all six countries combined for the whole sample period and the pre-crisis period, but not for the post-crisis period. Furthermore, the evidence suggests that government debt had negative effects on economic growth in most cases. The hypothesis that economic growth does not Granger-cause government debt is also rejected for all six countries combined and for most individual countries during all three sample periods. The results also indicate that economic growth contributed to the reduction in government debt. Based on our findings, it is suggested that excess government debt should be avoided to render a healthy economic growth, and that economic growth is the antidote in reducing government indebtedness.

\section{References}

Abbas, S. M. A. \& Christensen, J. E. (2007). The Role of Domestic Debt Markets in Economic Growth: An Empirical Investigation for Low-Income Countries and Emerging Markets, IMF, Working Paper/07/127.

Afonso, A., \& Jales, J. T. (2013). Growth and Productivity: The Role of Government Debt. International Review of Economics and Finance, 25, 384-407. https://doi.org/10.1016/j.iref.2012.07.004

Barro, R. (1989). The Ricardian Approach to Budget Deficits. Journal of Economic Perspective, 3, 37-54. https://doi.org/10.1257/jep.3.2.37

Baum, A., Checherita-Westphal, C. \& Rother, P. (2013). Debt and Growth: New Evidence for the Euro Area, Journal of International Money and Finance, 32, 809-821. https://doi.org/10.1016/j.jimonfin.2012.07.004

Easterly, W. R. (2001). Growth Implosions and Debt Explosions: Do Growth Slow Downs Cause Public Debt Crisis? Contributions to Macroeconomics, 1-24.

Granger, C. W. J. (2004). Time Series Analysis, Cointegration and Applications. American Economic Review, 94(3), 421-425. https://doi.org/10.1257/0002828041464669

Herndon, T., Ash, M. \& Pollin, R. (2013) Does High Public Debt Consistently Stifle Economic Growth? A Critique of Reinhart and Rogoff, Political Economy Research Institute Working Paper 322, University of Massachusetts Amherst.

Mondigliani, F. (1961). Long-run Implications of Alternative Fiscal Policies and the Burden of the National Debt. The Economic Journal, 71, 730-755. https://doi.org/10.2307/2228247

Panizza, U. \& Presbitero A. (2012). Public Debt and Economic Growth: Is There a Causal Effect? Working Paper, No.78.

Reinhart, C.M. \& Rogoff, K. (2010). Growth in a Time of Debt. Working Paper 25639, National Bureau of Economic Research. https://doi.org/10.3386/w15639 